\title{
Immigrant students in the Chilean school system: Interculturality and inclusion
}

\author{
Ma. Antonia Vollrath* \\ School of Nursing, Faculty of Sciences, Universidad Mayor, Chile
}

Received: July 1, 2021

Accepted: September 15, $2021 \quad$ Online Published: September 17, 2021

DOI: $10.5430 /$ jnep.v12n2p11

URL: https://doi.org/10.5430/jnep.v12n2p11

\begin{abstract}
According to current estimates, there are 244 million migrants worldwide, corresponding to $3.3 \%$ of the world's population. In the Americas, the number of migrants increased by $36 \%$ during the year 2015. The purpose of this bibliographic study was to explore and describe the state of the art of social inclusion of immigrant students in the Chilean school system. The method in this article was a review of scientific evidence updated out in the main databases available MedLine and The Cochranre Library Plus (PubMed, Lilacs, Scielo, EBSCO, Google Scholar), without date restriction, in Spanish, Portuguese and English. There were no restrictions regarding the type of study, without a date limit), 62 articles were selected. The increase of the foreign population in short periods of time exposes the migrant population to difficulties such as living in disorganization, and the need to adapt to the culture and customs of the host society, as well as traumatic events like abuse, discrimination, difficulties in access to health, educational and social services, lack of support networks and social articulation, which can have an impact on the physical and mental health of migrant populations. In Chile, it is still necessary to work to achieve intercultural education; indigenous people are still related to bilingual intercultural education. In conclussion, the diversity is a natural fact, therefore in this context it is suggested to create a vision of a culture of relations between diverse groups. Likewise, topics such as nationalism, identity, institutionalized attitudes of discrimination, xenophobia and racism, that still exist in the national culture, should be addressed.
\end{abstract}

Key Words: Students, Emigrants and immigrants, Adaptation, Emotional, State-of-the-Art, Review, Social inclusion

\section{INTRODUCCION}

The historical context of the migratory phenomenon that has occurred in the country especially in the last decade, impacting the Chilean educational system. According to figures for 2015, an enrolment of 30,625 foreign students is reported, an amount that in 2017 reached 77,608. Chile has the great challenge of working to achieve an inclusive and intercultural education, it is suggested that we must work on nationalism, identity, institutionalized attitudes of discrimination, xenophobia and racism that still exist in our culture. ${ }^{[1-5]}$ The purpose of this bibliographic study was to explore and describe the state of the art of social inclusion of immigrant students in the Chilean school system. Schools are designed for socialization, social integration and meeting between students and families; this community plays a relevant role in integration, unfortunately in Chilean schools, a contradiction of racism and discrimination is evident, which can be resolved through public policies focused on the educational community. ${ }^{[6,7]}$

The Chilean school system must respond to the guidelines set forth in the General Education Law (20.370), the Indigenous Law (19.253) and ILO Convention 169, which decree those foreign students living in Chile have the right to access Chile.

Published by Sciedu Press 
education, with facilities to ensure that their school career is successful and under equal conditions, the main challenge is to ensure their adequate intercultural inclusion. ${ }^{[8]}$

This project will contribute to strengthen the management and technical-administrative approach to the impact of the migratory phenomenon in the school system, because it will make visible the existing synergy between the actors such as immigrant students, teachers and principals involved in the process of change towards an inclusive and intercultural education and with respect to the practical, it will contribute to the visualization of the actions and strategies used that facilitate or hinder the process of improving school coexistence and show how ministerial regulations are implemented in the local reality, allowing to reflect on possible requirements for modifications based on the scientific evidence generated and finally, this experience can be extrapolated to other schools of the commune and/or region.

On the other hand, it seeks to deepen the social interactions that occur in the school space, the integration and inclusion of foreign children in the Chilean educational system is raised as a problem. In the municipal educational centers of Santiago, where the enrolment of foreign students in 2018 reached a $37.03 \%$ of the total of 33,042 students enrolled, ${ }^{[9]}$ and the concentration of foreign students at the basic school level is such that 11 of them have more than $30 \%$ of their total enrolment, and in 3 of them more than $50 \%,{ }^{[10]}$ it is emphasized that the current educational plan has focused on promoting an inclusive school. In addition, it will be developed in Santiago, because they have a school context with classrooms with more than $50 \%$ of foreign students, and they have carried out a curricular innovation with cultural relevance oriented to South American cultural integration processes, with concrete initiatives such as integration activities, thus strengthening interculturality and the understanding of migrations. ${ }^{[11,12]}$ However, there is also evidence of racial discrimination, racist and xenophobic violence against migrant children when they enter school. ${ }^{[7,13-18]}$

\section{METHOD}

This article compiles a review carried out in the main scientific bibliography databases available MedLine and The Cochranre Library Plus (PubMed, Lilacs, Scielo, EBSCO, Google Scholar), government institutions pages, without date restrictions, in Spanish, Portuguese and English. There were no restrictions regarding the type of study, with no date limit. The abstracts and full articles were reviewed, regarding the search strategy in the Medline database, the terms of the Medical Subject Headings (MeSH) were used, 62 articles were selected on the topic of social inclusion of immigrant schoolchildren.

\section{RESULTS AND DISCUSSION}

\subsection{Migration and its implications}

According to current estimates, there are 244 million migrants worldwide, corresponding to $3.3 \%$ of the world's population, ${ }^{[19]}$ in the Region of the Americas, the number of migrants increased by $36 \%$ during the year 2015. ${ }^{[20]}$ The development of migratory flows is a complex, dynamic phenomenon, which leads to ethnic and cultural diversity in the host countries, transforming identity and diluting traditional borders, producing impacts both in the territorial, social, economic, environmental and political context in the countries experiencing it, there are also processes of inclusion and exclusion in which not all individuals manage to be included in both the group that migrates and the society that hosts them. ${ }^{[21-25]}$

Individuals or groups migrate for various reasons among which, looking for better job opportunities, economic, study or family reunion among others. ${ }^{[21]}$ The increase of the foreign population in short periods of time exposes the migrant population to obstacles, challenges such as living in disorganization, the need to adapt to the culture and customs of the host society, a series of traumatic events also, such as risks of abuse, discrimination, difficulties in accessing health, educational and social services, lack of support networks and social articulation, which can have an impact on the physical and mental health of migrant populations. ${ }^{[26-29]}$

\subsection{Migration in Chile}

During the last two decades, Chile has been one of the most attractive countries for South American migrants, according to figures from the National Socioeconomic Characterization Survey30, there are 777,407 foreigners resident in the country, mainly from neighboring countries, such as Peru $29.9 \%$, Colombia $14.9 \%$, Bolivia 10.1\%, Argentina; $11.9 \%$, since 2014 there has been a sustained increase from Haiti, reaching $9.8 \%$ and Venezuela $24.2 \%$, it is noted that $71.8 \%$ of the total number of foreigners is concentrated in the Metropolitan Region. On the other hand, Survey indicates that $10.8 \%$ of immigrants are in a situation of poverty, according to multidimensional poverty indicators highlights immigrants lacking in social security $35.2 \%$, habitability $81.3 \%$ rented housing, equal treatment $32.2 \%, 65.1 \%$ have FONASA health insurance, a $81.3 \%$ is part of the labor force. With regard to access to education, the primary and secondary school attendance rate is significant for immigrant children aged 6 to 13, which represents a $71.1 \%$, and for adolescents aged 14 to $17,57.2 \%$ in the Metropolitan Region. ${ }^{[30]}$

\subsection{Migration of children and adolescents}

Historically, childhood has been invisible in the great events of the adult world, so it is relevant to consider it as "subjects 
of rights" and "social actors" in the daily family life, school and society in general. ${ }^{[31]}$ According to UNICEF data, there are currently 6.3 million migrant children and adolescents under the age of 18 in the Americas. ${ }^{[32]}$ It should be noted that adolescents are in a period of transition in which they begin to change the structure of their thinking, from a concrete structure to a more deductive one, logic and formal, in the case of girls, they prioritize activities related to social practices and participation in peer groups during the socialization process. ${ }^{[33]}$

With regard to the process of family migration faced by children and adolescents, it is generally necessary to comply with family reunification. ${ }^{[34]}$ Studies carried out on immigrant girls indicate that they need to be accepted by their peers, adopting as their own the values and practices of the children of the hosting place, ${ }^{[13]}$ the immigrant adolescents, have the imperative need to find their own space, a place to assert oneself, ${ }^{[35]}$ other studies show that girls undergo the process of adaptation with cultural assimilation and school victimization running in parallel, ${ }^{[36]}$ according to a study carried out in Spain with children of 5th grade, they held negative stereotypes towards their immigrant peers. ${ }^{[37,38]}$

In another context, a study reports that the integration of immigrant children is imperative, in which successful integration has depended to a large extent on the ability of the education system to integrate children growing up in immigrant households in conditions of social vulnerability, which has posed a challenge to the hosting countries. ${ }^{[39,40]}$ The integration of the immigrant child depends on some fundamental factors, such as the family and adequate schooling, this represents the beginning of integration and acts as a catalyst of normality for the family group. ${ }^{[41]}$ The evidence indicates that during the process of adaptation, immigrant children and adolescents may have feelings of insecurity and integration difficulties due to negative experiences of discrimination, due to the language, expressions and codes different from those that they know, ${ }^{[14]}$ it is also relevant to mention that the child population has fewer emotional resources to face new contexts, which can provoke a development different from the rest of their peers with whom they share their environment. ${ }^{[42]}$ In Chile, unfortunately, there are immigrant families that have experienced problems when it comes to finding a school for their children, both for reasons of quota, for excessive formalities, or for manifest prejudice. ${ }^{[6]}$

\subsection{Intercultural and inclusive integration is a challenge}

Facing the increasing migratory scenario, it demands from Chilean society challenges mainly in the ways of interacting between cultures and becoming an intercultural citizenship, ${ }^{[11,43]}$ therefore, it is imperative to expedite the processes

Published by Sciedu Press of improvement and updating of the Migration Law and public policies especially in the field of health, education and social development, where the challenge is installed, in order to give concrete response related to social integration, interculturality and school insertion 30, the phenomenon needs to be addressed responsibly.

It is here that the challenge arises to understand what interculturality proposes, which is a dynamic process that links relations, negotiations and exchanges between cultures that cohabit in a given space, and implies an equitable interaction between cultures, with a recognition of social, political, cultural differences in which there is no culture superior to the other; the supreme purpose of interculturality is to acquire and exchange the positive aspects of each one where the exchange should be viewed as an opportunity for inclusion to generate joint cultural and social expressions. ${ }^{[1,44-46]}$

Interculturality can also be understood as a strategy of transformation of hegemonic routines both organizational, structural and knowledge transmitted by generations, these strategies can be critical reflection, commitment and desire for change especially in the area of education where historical exclusion positions are reproduced. ${ }^{[11,47]}$ An inclusive intercultural school system is a key space in the generation of learning, encounter, coexistence and communication between different cultures; the school plays a fundamental role in the processes of cultural and social adaptation and integration, in immigrant children and adolescents. ${ }^{[48,49]}$ In the context of today's multicultural society, inclusive intercultural education is increasingly needed, it has the capacity to enhance equal outcomes for those in an unfavorable position. ${ }^{[11]}$

\subsection{Contextualization of the migratory phenomenon in schools in Chile}

According to a study carried out in 2016, $82 \%$ of migrant children reside mainly in three regions; Metropolitan, Antofagasta and Tarapacá; $56 \%$ are enrolled in municipal schools, ${ }^{[50]}$ for the year 2015 is reported an enrollment of 30,625 foreign students, amount that in 2017 reached $77,608 .{ }^{[51]}$ In Chile, it is still necessary to work to achieve intercultural education, indigenous population is still related to bilingual intercultural education, in turn it is proposed that diversity is a natural fact, it is in this context that it is suggested to create a vision around "culture" of the relations between diverse groups, likewise we must also work on nationalism, identity, institutionalized attitudes of discrimination, xenophobia and racism ${ }^{[1-5,7]}$ that still exist in the national culture.

The schools are designed for socialization, social integration 
and meeting between students, families and the community playing a relevant role in integration, however, in Chilean schools show a contradiction of racism and discrimination, which can be resolved through public policies focused on the educational community. ${ }^{[6,7]}$

In the country, the issue of inclusion is seen at the level of educational policy as a challenge, to be effectively applied in the Chilean schools, it has been visualized the need to update public policies with indications and guidelines, these policies grant some local autonomy in the implementation of an inclusive educational process appropriate for immigrant students from different cultures, languages and promote interculturality, respecting the diversity of gender, culture, religion, as noted by the Ministry of Education in Decree $\mathrm{N}^{\circ}$ 83, Ordinary $\mathrm{N}^{\circ} 02 / 000894$ and instructions on the admission, stay and exercise of the rights of migrant students in the country's school. ${ }^{[52-54]}$ Furthermore, the Ministry of Education, through the General Education Act $(20,370)$, the Indigenous Act $(19,253)$ and ILO Convention 169, indicates that foreign students living in Chile have the right to access education, having facilities to make their school trajectory successful and under equal conditions, the main challenge is to make sure and adequate inclusion with intercultural approach. ${ }^{[8]}$

\subsection{Educational system of Santiago city}

This study will be carried out in the municipal schools of Santiago, where foreign students enrolled in 2018 reached $37.03 \%$ of the total of 33,042 students enrolled $^{[9]}$ and the concentration of foreign students at the elementary school level is such that 11 of them have more than $30 \%$ of their total enrolment, and in 3 of them it is more than $50 \% .^{[10]}$ Coincidentally, this issue of immigration in the school has been pointed out within the three axes that the Annual Plan of Educational Development (PADEM) of Santiago will promote for the next years, specifically regarding the quality of education and specifically with regard to educational quality and school inclusion and, by the MINEDUC in the guidelines to promote an inclusive school. In addition, the Municipal Education Directorate of Santiago has the "Migrants Program", which aims to provide communal guidelines, aimed at facilitating the access and maintenance in the school system of foreign students and their families and the promotion of inclusive practices within educational communities, implemented in the 44 schools of the commune. ${ }^{[10]}$

Over time, various studies have been carried out in Santiago in 2010, in the school Republica de Alemania, a curricular innovation was carried out with cultural relevance oriented to South American cultural integration processes, with concrete initiatives such as integration activities where they paint flags of countries representing the countries of foreign stu- dents, thus strengthening interculturality and understanding of migration. ${ }^{[11,12]}$

Other studies carried out confirmed the numerous mechanisms of racial exclusion and discrimination, racist and xenophobic violence suffered by migrant children in their daily insertion into Chile, to this of the utmost deficiencies of the institutions that are not prepared to cover the needs of reception that will help them to organize their lives. ${ }^{[7,13-18]}$

There is no doubt that teachers have a fundamental role in integrating foreign students into the educational system, studying the perception of teachers with migrant students, highlights that $91.2 \%$ of them believe that they are a contribution for native students to know other cultures, however, 93\% point to the need to adapt training to intercultural reality. ${ }^{[55]}$ What stands out among the challenges is that teachers receive training and instruction, in order to carry out the appropriate educational actions in order to achieve an inclusive and intercultural education, on the other hand as a priority task it is necessary a curricular modification, management teams and trained teachers, it is also necessary to optimize resources to consolidate strategic alliances between schools with similar characteristics. ${ }^{[56,57]}$ Study on teaching and migration reveals that teachers propose support strategies such as having intercultural mediators in schools, with integration programs from admission to strengthen feelings of belonging to the educational establishment. ${ }^{[5]}$ Lastly, it should be mentioned that, since 2002, the Colectivo Sin Fronteras has been working to promote the rights of migrant children in Chile, intervening and promoting better conditions for the educational, social and cultural integration of children in Chile. ${ }^{[58]}$ Social representations mean the way in which people produce, reproduce and transform society, these are constructed from processes of social interaction and communication, from conversations of everyday life, can be captured in images, ideas and beliefs full of feelings and emotions. ${ }^{[59]}$

According to a study, in some schools in Sweden a model of inclusion of immigrant students is implemented, this experience concludes that success or failure depends on those who carry out the actions such as teachers and school administrators. ${ }^{[60]}$ In Germany, immigrant students are the center of attention in schools, due to the challenge of mastering the German language. This highlights the complexity of inclusive and exclusive actions at the structural and practical level in the school. ${ }^{[61]}$ Another study, on educational strategies to promote intercultural inclusion in a public secondary school in Barcelona, Spain, with the purpose of identifying and analyzing teaching practices that work towards intercultural inclusion, concludes that the success of the work depends on the management team and commitment assumed by teachers. 
These practices should be strengthened with the constant review of the dynamics and methodologies used. ${ }^{[62]}$

\section{Conclusions}

In conclusion, diversity is a natural fact, therefore in this context it is suggested to create a vision of a culture of relationships between diverse groups. The evidence reviewed suggests that interventions should be aimed at facilitating the social inclusion of immigrant schoolchildren, with positive experiences at school such as motivation, academic success, and psychological well-being. The study serves as reference information on the state of the art of social inclusion of immigrant students in the school system and serves as evidence of new strategies to address the situation or for future research.

\section{CONFlicts OF INTEREST Disclosure}

The authors declare that there is no conflict of interest.

\section{REFERENCES}

[1] Poblete R, Galaz C. La identidad en la encrucijada: migración peruana y educación en el Chile de hoy. EMIGRA working papers. 2007; (3): 0001-19.

[2] Abarca G. Educación intercultural bilingüe y los desafíos de su implementación. Cuaderno de Educación. 2015 [cited 2019 Mar 3]; 70: $1-5$.

[3] Quilaqueo D, Torres H. Multiculturalidad E Interculturalidad: Desafíos Epistemológicos De La Escolarización Desarrollada en Contextos Indígenas. Alpha: Revista de Artes, Letras y Filosofía [Internet]. 2013 Dec [cited 2019 Mar 3]; (37): 285-300. https: //doi.org/10.4067/S0718-22012013000200020

[4] Riedemann A. La Educación Intercultural Bilingüe en Chile: ¿ampliación de oportunidades para alumnos indígenas? Indiana [Internet]. 2008 [cited 2019 Mar 3]; (25).

[5] Williamson G. Institucionalización de la educación intercultural bilingüe en Chile. Notas y observaciones críticas. Perfiles Educativos [Internet]. 2012 [cited 2019 Mar 3]; 34(138): 126-147. https : //doi.org/10.22201/iisue.24486167e.2012.138.34159

[6] Stefoni C, Acosta E, Gaymer M, et al. El derecho a la educación de los niños y niñas inmigrantes en Chile, Cuadernos Deusto de Derechos Humanos Núm. 58, Bilbao, Universidad de Deusto. [Internet]. 2010 [cited 2019 Mar 3].

[7] Tijoux ME. Las escuelas de la inmigración en la ciudad de Santiago: Elementos para una educación contra el racismo. Polis (07176554) [Internet]. 2013 May [cited 2019 Mar 25]; (35): 2-15.

[8] Ministerio de Educación de Chile. Escuela intercultural. Institucionalidad [Internet]. 2019 [cited 2019 Mar 3]. Available from: http://peib.mineduc.cl/institucionalidad/

[9] Departamento de Edición Municipalidad de Santiago. Resumen comunal 2018. Programa migrantes inclusión y diversidad educativa. Depto. Psicosocial y bienestar estudiantil. Dirección de educación municipal de Santiago 2018.pdf. [cited 2019 Mar 3].

[10] Plan de Desarrollo Educativo Municipal. PADEM 2018. Dirección de Educación Municipalidad de Santiago [Internet]. 2018 [cited 2019 Mar 3]. Available from: http://www .educasantiago.cl/wp-c ontent/uploads/2018/01/1-PADEM2018.pdf

[11] Mardones P. Somos iguales, somos diferentes. Migrantes en Chile mirados desde la escuela. VII Congreso Chileno de Antropología. Colegio de Antropólogos de Chile A. G, San Pedro de Atacama [Internet]. 2010 [cited 2019 Mar 3].

[12] Alvites S, Jiménez A. Niños y niñas migrantes, desafío pendiente. Innovación educativa en escuela de Santiago de Chile. Synergies Chili [Internet]. 2011 [cited 2019 Mar 3]; (7): 121-136.

Published by Sciedu Press
[13] Pavés I. Los significados de "ser niña y niño migrante": conceptualizaciones desde la infancia peruana en Chile. Polis (07176554) [Internet]. 2013 May [cited 2019 Mar 3]; (35): 2-19.

[14] Tijoux-Merino ME. Niños(as) marcados por la inmigración peruana: estigma, sufrimientos, resistencias. Convergencia: Revista de Ciencias Sociales [Internet]. 2013 Jan [cited 2019 Mar 3]; 20(61): 83-104.

[15] Pávez-Soto I. Inmigración y racismo: experiencias de la niñez peruana en Santiago de Chile. Si somos americanos: Revista de Estudios Transfronterizos, XII [Internet]. 2012[cited 2019 Mar 3]; (1): 75-99. https ://doi.org/10.4067/S0719-09482012000100004

[16] Riedemann A, Stefoni C. Sobre el racismo, su negación, y las consecuencias para una educación anti-racista en la enseñanza secundaria chilena. (Spanish). Polis (07176554) [Internet]. 2015 Sep [cited 2019 Mar 3]; (42): 1. https ://doi.org/10.4067/S0718-656820150 00300010

[17] Tijoux ME. Racismo en Chile. La piel como marca de la migración. Santiago: Editorial Universitaria [Internet]. 2016 [cited 2019 Mar 3].

[18] Tijoux ME, Rivera MGC. Racismo en Chile: colonialismo, nacionalismo, capitalismo. (Spanish). Polis (07176554) [Internet]. $2015 \mathrm{Sep}$ [cited 2019 Mar 3]; (42): 1. https://doi.org/10.4067/S071 8-65682015000300001

[19] Organización de Naciones Unidas. ONU. Migración. OIM, Informe de migraciones en el mundo [Internet].2018 [cited 2019 Mar 15] Available from: https://publications.iom.int/system/fi les/pdf/wmr_2018_sp.pdf

[20] Organización Mundial de la Salud. OMS. Informe Promoción de la salud de los migrantes [Internet]. 2016 Dec [cited 2019 Mar 15] Available from: http://publications.iom.int/system/file s/wmr2015_sp.pdf

[21] Organización Mundial de la Salud. OMS. Salud en las Américas. Migración Nacional e internacional [Internet]. 2017 [cited 2019 Mar 15]. Available from: https://www.paho.org/salud-en-las-a mericas $-2017 /$ ?post_type=post_t_es\&p=313\&lang=es

[22] PINYOL-JIMÉNEZ G. Sobre migraciones y refugio: de los conceptos y de su marco normativo en el escenario internacional. Tiempo de Paz [Internet]. 2017 Dec [cited 2019 Mar 3]; (127): 17-25.

[23] Mondaca C, Gajardo Y. La educación intercultural bilingüe en la región de Arica y Parinacota, 1980-2010. Diálogo andino [Internet]. 2013 [cited 2019 Mar 3]; (42): 69-87. https ://doi .org/10.406 7/S0719-26812013000200007

[24] Castles S. Globalización y migración: algunas contradicciones urgentes. Discurso inaugural presentado en la reunión del Consejo Intergubernamental del MOST/UNESCO [Internet]. 1997 Jun [cited 2019 Mar 3]; 16. 
[25] Melis P, Álvarez C, Barrera F, et al. NIÑOS Y NIÑAS MIGRANTES TRAYECTORIAS DE INCLUSIÓN EDUCATIVA EN ESCUELAS DE LA REGIÓN METROPOLITANA INFORME FINAL DE INVESTIGACIÓN. Superintendencia de Educación de Chile [Internet] 2016 Nov [cited 2019 Mar 3].

[26] Urzúa A, Heredia O, Caqueo-Urízar A. Salud mental y estrés por aculturación en inmigrantes sudamericanos en el norte de Chile. Rev. méd. Chile [Internet]. 2016 May [cited 2019 Mar 3]; 144(5): 563-570. PMid:27552005 https ://doi.org/10.4067/S0034-9 8872016000500002

[27] Pedemonte R, Dittborn S. La migración en Chile: Breve reporte y caracterización. DEM 2016 Anuario estadístico nacional 2005 2014. Santiago de Chile: Departamento de Extranjería y Migración del Ministerio del Interior y Seguridad Pública [Internet]. $2016 \mathrm{Jul}$ [cited 2019 Mar 3]. Available from: https://www. extranjeria. gob.cl/media/2016/08/informe_julio_agosto_2016.pdf

[28] Organización Mundial de la Salud. OMS. Informe Promoción de la salud de los migrantes [Internet]. 2016 Dec. [cited 2019 Mar 3]. Available from: http://apps.who.int/gb/ebwha/pdf_files/ EB140/B140_24sp.pdf

[29] Instituto Nacional de Derechos Humanos (INDH). Informe Anual Situación de los Derechos Humanos en ChileCAP02_Informe-Anual-INDH-2016, Igualdad y no discriminación.pdf [Internet]. 2016 [cited 2019 Mar 3]. Available from: http://www.indh.cl/informe-anual-situacion-de-los -derechos-humanos-en-chile-2016

[30] Encuesta de Caracterización Socioeconómica Nacional (CASEN 2017. Minuta resultados Casen 2017 migrantes [Internet]. 2017 [cited 2019 Mar 3]. Available from: https://es.scribd.com/document/395977942/Los-d atos-de-la-encuesta-CASEN-2017\#from_embed

[31] Pavés I. Los derechos de las niñas y niños peruanos en Chile: La infancia como un nuevo actor migratorio. Revista Enfoques: Ciencia Política y Administración Pública [Internet]. 2010 [cited 2019 Mar 3]; 8(12).

[32] UNICEF 2018. [Internet]. 2018 [cited 2019 Mar 3]. Available from: https://www . unicef .org/lac/ni\%C3\%B1os-ni\%C3\%B1as-y -adolescentes-migrantes-y-refugiados-en-am\%C3\%A9r ica-latina-y-el-caribe

[33] Morales U, Toro J, Ramírez P. ¿Existen diferencias en la evaluación de la calidad de vida cuando los menores valoran la importancia de lo que se les pregunta? Arch Argent Pediatr [Internet]. 2013 [cited 2019 Mar 3]; 111(2): 98-104. https://doi.org/10.5546/aap. 2013.98

[34] Departamento de Protección de Derechos. Niños, niñas y adolescentes migrantes. Una mirada desde los proyectos de diagnóstico [Internet]. 2013 Nov [cited 2019 Mar 3]. Available from: http://www.sename.cl/wsename../otros/dam_2013 /NNA_MIGRANTES.pdf

[35] Giró J. Adolescencia, inmigración e identidad [Internet].2007 [cited 2019 Mar 3].

[36] Koo D, Peguero A, Shekarkhar Z. Gender, Immigration, and School Victimization. Victims \& Offenders [Internet]. 2012 Jan [cited 2019 Mar 3]; 7(1): 77-96. https://doi.org/10.1080/15564886.2 011.629773

[37] Rodríguez H, Retortillo Á. El prejuicio en la escuela: un estudio sobre el componente conductal del prejuicio étnico en alumnos de quinto de primaria [Internet]. 2006 [cited 2019 Mar 3]; 20: 133-149.

[38] Cobo MO. Inmigración en las aulas: percepciones prejuiciosas de los docentes. Papers: Revista de Sociologia [Internet]. 2008 Jan [cited 2019 Mar 3]; (87): 253-68. https ://doi .org/10.5565/rev/pa pers/v87n0.805
[39] Dreby J. How Today's Immigration Enforcement Policies Impact Children, Families and Communities: A View from the Ground. Center for American Progress: Washignton, D.C. [Internet]. 2012 Aug [cited 2019 Mar 3].

[40] Stacciarini J-MR, Smith R, Garvan CW, Wiens B, Cottler LB. Rural Latinos' mental wellbeing: a mixed-methods pilot study of family, environment and social isolation factors. Community Mental Health Journal [Internet]. 2015 May [cited 2019 Mar 3]; 51(4): 404-13. PMid:25185562 https://doi.org/10.1007/s10597-014-977 4-z

[41] Alba R, Sloan J, Sperling J. The integration imperative: The children of low-status immigrants in the schools of wealthy societies. Annual Review of Sociology [Internet]. 2011 Aug [cited 2019 Mar 3]; 37: 395-415. https://doi.org/10.1146/annurev-soc-0 81309-150219

[42] Petit JM. Migraciones, vulnerabilidad y políticas públicas. Impacto sobre los niños, sus familias y sus derechos. Serie Población y Desarrollo, No 38. CELADE- BID. Chile [Internet]. 2003 [cited 2019 Mar 3]. Available from: https ://www. cepal.org/es/pub licaciones/7178-migraciones-vulnerabilidad-politic as-publicas-impacto-ninos-sus-familias-sus

[43] Poblete R. Educación intercultural en la escuela de hoy: reformas y desafíos para su implementación. Revista Latinoamericana de Educación Inclusiva [Internet]. 2009 [cited 2019 Mar 3]; 3(2): 181-200.

[44] Mora ML. Política educativa para migrantes en Chile: un silencio elocuente. Polis (Santiago) [Internet]. 2018 [cited 2019 Mar 15]; 17(49): 231-257. https://doi.org/10.4067/S0718-6568201 8000100231

[45] Hirmas C, Hevia R, Treviño E, et al. Políticas Educativas de Atención a la Diversidad, Brasil, Chile, Colombia, México, Perú. Vol. 1. UNESCO, [Internet]. 2005 [cited 2019 Mar 3].

[46] Walsh C. Interculturalidad, conocimientos y decolonialidad. Signo y pensamiento [Internet]. 2005 [cited 2019 Mar 3]; 24(46): 39-50.

[47] Jiménez F, Aguilera M, Valdés R, et al. Migración y escuela: Análisis documental en torno a la incorporación de inmigrantes al sistema educativo chileno. Psicoperspectivas [Internet]. 2017 Mar [cited 2019 Mar 3]; 16(1): 105-116. https://doi.org/10.5027/psicoper spectivas-Vol16-Issue1-fulltext-940

[48] García-Cano M, Márquez E, Antolínez I. A learning community from the intercultural approach: dialogues, emergencies and contradictions in school practice. Educación XX1 [Internet]. 2016 [cited 2019 Mar 3]; 19(2): 251-271.

[49] Walsh C. Interculturalidad crítica y pedagogía decolonial: In-surgir, re-existir y revivir. UMSA Revista (entre palabras) [Internet]. 2009 [cited 2019 Mar 3]; 3.

[50] Joiko S, Vásquez A. Acceso y elección escolar de familias migrantes en Chile: No tuve problemas porque la escuela es abierta, porque acepta muchas nacionalidades. Calidad en la educación, [Internet]. 2016 [cited 2019 Mar 3]; (45): 132-173. https://doi.org/10.4067/S0718-45652016000200005

[51] Fernández M. P. Mapa del estudiantado extranjero en el sistema escolar chileno (2015-2017) Centro de Estudios MINEDUC. Santiago, Chile [Internet]. 2018 [cited 2019 Mar 15].

[52] Ministerio de Educación de Chile. Marco para la buena dirección y el liderazgo escolar. Mineduc, Santiago, Chile [Internet]. 2015 [cited 2019 Mar 3]. Available from: https://liderazgoescolar.mineduc.cl/marco-par a-la-buena-direccion-y-el-liderazgo-escolar/

[53] Ministerio de Educación de Chile. Ordinario $\mathrm{N}^{\circ} 000894$ "actualiza las instrucciones instruye sobre el ingreso, permanencia y ejercicio de los derechos de estudiantes migrantes 
en los establecimientos que cuentan con reconocimiento oficial" [Internet]. 2016 [cited 2019 Mar 3]. Available from: https://migrantes.mineduc.cl/wp-content/uploads/s ites/88/2017/04/7-ORD.894-Mineduc-Migrante.pdf

[54] Ministerio de Educación de Chile. Educación Intercultural [Internet]. 2017 [cited 2019 Mar 3]. Available from: http://portales.mineduc. cl/index 2 .php?id_portal=2 8\&id_seccion $=5428 \& i d$ _contenido $=33816$

[55] Ministerio de Educación de Chile Informe: Estudio Censo Docente Migración. Su impacto en la práctica docente [Internet]. 2018 [cited 2019 Mar 3]. Available from: https://migrantes.mineduc.cl/2017/09/29/estudi o-medira-impacto-la-migracion-la-practica-docente/

[56] Flores G, Prat M, Soler S. La voz del profesorado de educación física sobre su formación académica ante la realidad multicultural: análisis de la situación y propuestas de mejora. Revista Electrónica Interuniversitaria De Formación del Profesorado [Internet]. 2014 Apr [cited 2019 Mar 3]; 17(2): 183-99. https://doi.org/10.6018/reif op.17.2.197501

[57] Donoso A, Mardones P, Contreras R. Propuestas y desafíos a partir de la experiencia de una escuela con migrantes en el Barrio Yungay, Santiago de Chile. Docencia [Internet]. 2009 [cited 2019 Mar 3]; 37: $56-62$.
[58] Colectivo Sin Fronteras. Niños y niñas migrantes. Políticas públicas, integración e interculturalidad. Santiago: Editorial Quimantú 2007 [cited 2019 Mar 3].

[59] Olivares-Donoso Ruby. Las representaciones sociales de la clasificación de escuelas presentes en los discursos en medios de comunicación escritos. Estudios pedagógicos (Valdivia) [Internet]. 2015 [cited 2019 Mar 3]; 41(2): 195-211. https://doi.org/10.4067/ S0718-07052015000200012

[60] Tajic D, Bunar N. Do both 'get it right'? Inclusion of newly arrived migrant students in Swedish primary schools. International Journal of Inclusive Education [Internet] 2020 [cited 2021 Sep 14]; 1-15. https://doi.org/10.1080/13603116.2020.1841838

[61] Terhart H, von Dewitz N. Newly arrived migrant students in German schools: Exclusive and inclusive structures and practices. European Educational Research Journal [Internet] 2017 [cited 2021 Sep 14]; 17(2): 290-304. https://doi.org/10.1177/14749041177226 23

[62] Ocampo-Torrejón S, Rivera-Vargas P, Hernández-Hernández F. Educational strategies to promote intercultural inclusion at a public secondary school in Barcelona. Annales-Anali za Istrske in Mediteranske Studije-Series Historia et Sociologia. 2020; 30(4): 643-656. 